\title{
The Effectiveness of a Computer Program Based on Photoshop in Design and Decoration and Its Impact on Emotional Intelligence Among Children Aged
} (11-17 Years) At Jazan Region, Kingdom Saudi Arabia

Mahasin Gad Alla Mohamed"1, Khalida Mohammed Mahmoud², Abeer Amir Bashir ${ }^{3}$ Educational Technology Dept., Jazan University, Jazan, Saudi Arabia ${ }^{1}$

Psychology Dept., Jazan University, Jazan, Saudi Arabia ${ }^{2}$

Art Education Dept., Jazan University, Jazan, Saudi Arabia ${ }^{3}$

Article Info

Volume 8, Issue 3

Page Number : 670-690

\section{Publication Issue}

May-June-2021

\section{Article History}

Accepted : 10 June 2021

Published : 17 June 2021

\section{ABSTRACT}

The aim of the research was to investigate the effectiveness of a computer based on photoshop in design and decoration and its impact on emotional intelligence among children in the age group (11-17 years). To achieve the research objectives, the researchers chose the quasi-experimental design with equal groups, the control group and the experimental group. The sample size was (44) students, (14) males and (30) females, who were chosen by random stratification method from the middle and high school levels in Jazan region in the age group (11-17). They were distributed into two equal groups (22) students for each of the control and experimental group. The researchers used the Bar-On scale for emotional intelligence in addition to the training program. The Statistical Package for Social Sciences (SPSS) program was used for analyzing data. The two-tailed T-Test was chosen to detect the differences between the binary groups and the univariate analysis. Variation: to detect differences between the interaction groups and the post-LSD test to determine the direction of the differences between groups of variable interaction (group $\mathrm{x}$ application). The research reached the following results: there are statistically significant differences in the average scores of children of age (11-17 years) on the emotional intelligence scale pre and post the application of the program, and there are statistically significant differences in the average performance of the experimental group on the emotional intelligence scale due to gender, and there are significant differences statistical differences in the average performance of the experimental group on the emotional intelligence scale due to age, and there are statistically significant differences in the average scores of 11-17 year old children on the emotional intelligence scale between the groups of variables of program application and type of education.

Keywords: Photoshop, Design, Decoration, Emotional Intelligence 


\section{INTRODUCTION}

\section{Background}

The nations that know how to face challenges in the world of technology and developments are the ones that are clearly aware that its pillar is against challenges, and it is formed from its civilized vision of education. Recent years witness a number of informational challenges of different dimensions in all fields, including the educational field as the information challenges in its various dimensions constituted a necessity to reform the educational system with all its inputs and outputs, so many nations are racing to reform their educational systems, with the aim of preparing their citizens for a technology-oriented world, as the world is looking for development in the educational model. Since education is our means to prepares the present and future generations, the advanced educational method becomes the best way to achieve the desired goal, and our life began to witness a distinct shift in the information and knowledge revolution at an accelerated pace, which made educational institutions enjoy it, so, it took upon itself to keep pace with this development, and began to transform its educational methods from indoctrination to modern methods that keeps pace with development to help the learner acquires educational competencies that enable him to play a positive role, and make him able to face life, use critical and creative scientific thinking, using information technologies and their advanced networks. Education-based on indoctrination and information stuffing leads to outputs that lack mastery and creative skills, which necessitates the acquiring of skills through thinking activities, and modern education style to build the personality of the learner (El-Sayed, 2004, p. 56).

The arts course is an important course in all educational institutions at different educational levels, as it is a course that provides the student with cognitive information related to his/her knowledge and practical life of design and decoration that works to develop the student's skills and creative abilities. Therefore, computers must be used in this field and linked to technology in education in the public education. Modern means must be placed in the appropriate place so that they can play their role in completing the educational goals, which in order to promote them came the role of the computer in developing the capabilities of design and decoration of all kinds in order to increase the effectiveness of teaching and learning and the promotion of the arts. The computer has impressed the world with its many great works, as its important role has emerged in spreading and developing human thought (AbdelBaqi, 2005, p.126).

Emotional intelligence as an emotional process requires three basic mental processes: awareness expression of the emotions of oneself and others, regulation of the emotions of oneself and others, and the adaptive use of emotions for the purpose of achieving one's own goals (Zee \& Wabeke, 2004, p 244).

The model of emotional intelligence as an ability stems from the idea that emotions include information about relationships (and other models also focus on the component of an individual's relationships with others and things), but what is important from the point of view of this model, is the information associated with these relationships, and these relationships are characterized as realistic and capable of remembering and imagination, as these relationships consist of a set of connotations of an emotional nature, and thus emotional intelligence is represented as an ability to "remember the meaning of emotions and the relationships between them, and to use those emotions as a cognitive basis for inference and problem solving." (Mayer \& Salovey, 2000, pp 411-413). 


\section{Theoretical framework}

\section{The Photoshop}

Photoshop means a workshop for images, and what is meant is that you can create, modify the layers, by isolating and controlling each layer from the other, in addition to its ability to express and create and show messages and ideas through design. The Photoshop program is relying on layers, which can be controlled, individually. Also, work is done through filters, which have effects on the design. These effects are ready-made movements, in addition to the tools. Photoshop has several versions in English and supporting the Arabic language. Quoted from (Khallad, 2002, pp1-2).

\section{Introduction to Photoshop}

\section{The history of photoshop}

There was a professor named "Glenn Knoll" at the University of Michigan. Glenn was fond of pictures and established a lab in the basement of his house. He also loved technology and was captivated by the advent of the personal computer. He had two sons, Thomas and John, and they inherited the characteristics of their father, an interest in the lab and added Apple II plus machine for the lab, Thomas was fond of photography, image display and color balance, and while Thomas was learning image processing in his father's lab, John was playing with his father's personal computer, which was replaced by a Macintosh in 1984, and this was an important achievement for John, Thomas was interested in image processing and began using computers for digital processing. John and Thomas began to ramp up their work and combine their efforts to collect those scattered codes to create a complete digital image processing program.

Thomas and John's happiness with what they achieved prompted them to ask for more, such as the ability to store images in different formats, the ability to open and print image files in other programs, and other new ideas. After several months of attempts,
Image Pro was produced. Glenn the idea of presenting what they have reached to companies, and here is the beginning of Photoshop, where the first version of Adobe Photoshop. Since then, the development of the program began (Al-Hariri, 2004, p. 13). The program is considered the most powerful image design program in all its forms in the world, and it gives you complete freedom to put anything in the image or change it depending on the layers system, which it works with, and its importance is great, as it is used among all Internet and design media in designing images, websites, forums and others, in addition to its availability and ease of use compared to major design programs.

\section{Photoshop supplements}

Photoshop is a program for designing images of all kinds, there are programs and supplements for photoshop to design complete websites, such as Illustrator, Corel Draw, Frontpage, Flash, 3D Max, Dreamweaver, and many auxiliary programs that help in producing a great work as a website. The reason for choosing this program is due to its multiple capabilities through the many tools that help the artist in making infinite formulations in building the decorative form, diversity, providing alternatives, storage and synthesis between units, in addition to the accuracy and speed in formulating these units. One of the advantages of this program in forming the painting is that the elements that make up the art board (layers) that can be controlled in each layer separately such as moving, reducing, zooming, reversing and repeating it, or adding tactile or color effects to this element, and shadows can be added to the shapes or make them prominent. or sunken, or rearrange these pounds, any elements according to the artist's vision. Photoshop also contains a set of many and multiple filters that give various effects such as the effect of Oil color, watercolor, pastel color, charcoal, wax, glass, ceramic, wood or mosaic. It is also possible to add various colored lights to the shapes that make up the artwork, and another set of 
filters can be added to the program that adds various other capabilities to the artist (Smith, 2021)

\section{Photoshop Features}

1. Photoshop is superior to other programs in the two most important things, which are the powerful selection tools and the concept of layers, which constitute half of the program's ability.

2. The program provides flexible possibilities to move the drawing in whole or in part, to rotate it axially, or to make a mirror for it, or to copy it in a flexible way with tilting it in different positions.

3. The command Qari filter can be used, which allows previewing the design before implementing it, and it also allows the use of more than one filter in one design, and the program contains drawing tools with high capabilities in the implementation of the drawing, such as different paintbrushes of different thickness, and there are multiple tools in selection properties.

4. A full explanation of color management and ways to achieve it efficiently to adjust the performance of computer-related devices (monitors, printers, scanning devices), to work on color stability during the output stage, in the help guide.

5. The possibility of undo-redo.

6. The program contains a list of instructions that help the user immediately.

7. The high possibility of making drawings in layers images with blocking parts of the drawing, and making paths with automatic recording of the stages of drawing and the effects that take place on it.

8. The possibility of photographing stereoscopic figures from all directions with a camera inside the program and the ability to view the images immediately

9. The possibility of moving and rotating the stereoscopic shapes in various directions to see their different conditions to choose the best one.
10. The possibility of painting any object with any material easily, such as glass, wood, copper, silver, gold, stones or marble of all kinds.

11. Putting the appropriate backgrounds to address the void in the painting

12. The program contains multiple tools for drawing that provide a high possibility in terms of designing ideas.

13. The paintbrush with its different characteristics in terms of thickness and artistic effects.

14. Multiple tools in the selection properties of different geometric, free and compound drawings, which allow the possibilities of starting the commands of coloring, cutting, copying, repeating, zooming in or out. (Mustafa, 2005, p. 30)

\section{Design software uses}

Students use design programs for several purposes, including the production of different technical units that address a problem, or the production of a poster, advertisement, or educational means. The poster is a type of an advertisement which has an important function of its means, due to its repetition and continuous communication with the recipient. The poster is designed for people in order to understand it from a quick look. It combines focused and brief visual effects, but it has a direct impact and is capable of attracting attention. The selected plastic elements play a prominent role in attracting the attention of the recipient to the meanings and expressive values contained in the poster, so that it achieves positive and effective effects in the viewer. Moreover, it contributes to artistic cultural awareness, and affects public awareness of that as well as an influential and problematic element for the environment. (Mustafa, 2005, p. 19).

Good design depends on achieving interaction between the poster design elements, and creating consistency between them, which gives a basis for integration in the design. Since the poster aims to 
attract the attention of the viewer, designer must coordinate all units within the poster, for him, in a way that prevents competition between poster terms, which gives beauty that achieves the poster goals.

\section{Decoration}

Decoration is one of the sciences of the arts that investigates the philosophy of abstraction, proportionality, composition, space, mass, color and line, which are either geometrical units or natural units (vegetal - human - animal), which have been transformed into their abstract forms, depending on the artist's imagination, sense and creativity. (Marzouk, 1988, p. 107)

The journey of decoration begins with man, since he was living in caves, in prehistoric times, was keen to decorate the walls of his cave with different decorations and different colors. These ages are the depicted animals and plants that are found in the environment in which they live, and some of the depicted animals and plants may have lived in the area in which the mural or inscription was found, and then became extinct, so it is possible to date the inscription or the image within the time period in which these animals lived or plants. (Fikri, 2000, p. 55)

Decoration bases, is the way in which drawings, designs and decorative, natural and geometric themes, taken or borrowed from nature, can be placed on technically and scientifically sound grounds. Before starting any design, the designer must provide the material used, the purpose of its use, the final form and the proportion. So, one of the most important laws and rules of decoration is the creation of decoration and its formation from nature, and these laws are endless. The journey of decoration, is a journey that expresses the development of human expression, of the aesthetics of the human soul's vision of the universe, and expresses the arts that show this aesthetics in their various forms through decorative arts, and it refers to everything that adorns existing buildings or beautifies transported artifacts, such as ceramics, fabrics, rugs, wood, ivory, glass, metals, leather and paper. (Marzouk 1988, p. 108)

\section{Computer capabilities in decorative painting design}

The computer provides the artist with new horizons and many possibilities for art and creativity when designing the decorative painting, which are:

1-Producing complex designs with precision and ease saves time, effort and hassle.

2-Preserving and storing items and art forms and quickly recovering some of the stored items.

3-It increases the mental ability of the designer, as it helps in making infinite formulations in building a single work.

4- The ability to change the location of shapes and colors for any part of the design.

5- The possibility of erasing or duplicating any part of the design easily and quickly.

6- It provides many artistic tools for the artist such as point, line, shadow, transparency, textures, colors and reflections of shapes. (Hamid, 1982, p. 100)

7- It allows the possibility of mixing colors accurately and the appearance of the mixed color sample immediately, and the brightness and intensity of the color can be determined.

8-Accurately control the drawing of lines and their types and the possibility of the color gradation of the line.

9-The ability to modify any part of the design with ceramics, add or change the places, proportions and positions of the images easily and conveniently.

10- The possibility of direct drawing and stereoscopic image.

11-The possibility of carrying out the decorative painting with the material that the artist wants, for example, watercolors, oil colors, or mosaics.

12- It allows re-designing any image in any color, using different light sources and controlling light, shadow and light reflections. 
13-The possibility of photographing stereoscopic figures from all directions with a camera inside the program and the possibility of viewing the images immediately. (Al-Basha, 1994, p88).

\section{Emotional intelligence}

Emotional intelligence studies have developed in an increasing manner and this casts a shadow over its concept and definition as well. However, it is possible to review some of the definitions contained in most studies and research, and one of the most prominent definitions is Mayer and Salovey, 1990, definition of emotional intelligence as: "the individual's ability to monitor feelings is his/her own emotions and feelings others and their emotions and distinguish between them, and that the individual uses this information in directing his/her behavior and emotions". Based on this definition, emotional intelligence includes the following abilities:

1- The individual's awareness and expression of his or her emotions and feelings.

2-Regulating the individual's emotions and the emotions of others.

3- Directing the behavior of the individual.

Another dimension has been added to the definition: the individual's ability to accurately perceive and express his/her emotions, to understand how emotions affect thought, to understand and infer from emotions, and to regulate emotions in a way that enhances emotional and mental development of the individual, and with this addition, emotional intelligence and thinking refers to cognitive intelligence (Samadouni, 2007, p. 102).

Emotional intelligence is a set of abilities that explain individual differences between individuals in their level of awareness and understanding of emotions. In a clearer form, it is the ability to perceive and express feelings and emotions, the ability to understand and justify feelings in oneself and others.
The most important development in the subject of intelligence is what was brought about by (Cheng and Lynn 2017), who defined emotional intelligence as a set of emotional skills that an individual possesses and necessary for success in interacting with others in different life situations, then he defined it as the individual's ability to know his/her feelings and the feelings of others to push himself/herself and manage His/her emotions effectively within himself/herself and his/her relationships with others. This definition includes a set of dimensions such as: knowing and managing one's own emotions, motivating oneself and empathizing with others, or what are called social skills (Abu Al-Nasr, 2008, 332).

\section{Axes of emotional intelligence}

1- The ability to be aware of one's feelings and emotions.

2- A person's awareness of his/her feelings and the feelings of others, and their understanding and awareness of them.

3- Controlling the feelings of the individual enables him/her to be able to extrapolate the feelings of others and control his emotions.

4- Using, controlling, and directing emotions and feelings in the individual and others.

5- Social interaction with others and empathy for their feelings. (Abu Al-Nasr, 2008, p. 332).

\section{Dimensions of emotional intelligence}

Emotional intelligence consists of several dimensions that are similar to each other in terms of concept and significance and can be clarified according to the perception of each scientist. Emotional intelligence consists of five dimensions:

Self-awareness: Self-awareness means awareness of one's own feelings, emotions, and moods as he/she spoke, as well as awareness of his/her thoughts about them. Self-awareness is the basis of self-confidence and efficiency in managing it, and it is the basis on which a person relies in making his/her various life decisions. Self-regulation: it means how the 
individual deals with negative feelings and emotions that harm and disturb him/her, and how to get rid of them and turn them into positive emotions. It includes self-regulation (emotional management or self-control).

Motivation: It is the motive that drives an individual's behavior, whether it is (internal or external), to achieve a specific goal. The basic rule is that every behavior has a motive, and hope is one of the basic components of motivation, which means that the individual has a goal and knows the necessary steps to achieve it, and that he has enthusiasm and perseverance constantly striving towards it.

Empathy and understanding: The concept of empathy refers to the individual's ability to read the feelings of others from their voices or facial expressions, recognize them and respond to them. Non-verbal expressions are much truer than verbal expressions, as language often fails to express what the individual feels or thinks, and therefore expressions are the face, tones, and gestures are truer in expression. A person may agree with his tongue, while his face and voice indicate rejection. It also includes the individual's ability to perceive and understand the feelings of others.

Social skills: They refer to the positive and strong influence on others by being aware of their emotions and feelings, knowing when to lead and when to follow others, support them and act with them in an appropriate manner, build trust and form a successful social network. (Cheng \& Lynn, 2017, p12)

\section{Previous studies}

Al-Fraihat (2018) study was aimed to reveal the effectiveness of a training program to develop emotional intelligence skills among students of King Abdullah II School in Ajloun Governorate in Jordan. A sample of tenth grade students, whose number (50), male and female students was chosen. The study tools were emotional intelligence scale and training program, which was applied to the experimental group. The results showed that there were differences in the average of the experimental group members on the emotional intelligence scale in favor of the experimental group, and there were no statistically significant differences between males and females.

Marzuok and Al-shrbeni (2013) study was conducted to verify the effectiveness of a training program in developing emotional intelligence and its impact on developing social skills for children with attention deficit hyperactivity disorder in the primary school. The study sample consisted of (26) children with hyperactivity and attention deficit disorder in the sixth grade of primary school in Qena city, 12 were males and 14 were females. The emotional intelligence scale and the social skills scale that prepared by the researchers, was applied to them. The program was applied. The training method has been using means, standard deviations, One-Winty test and Wilcoxon test. The results concluded that the children's social skills and emotional intelligence improved, the effectiveness of the program, and there were no differences between males and females.

Jabr (2010) study was aimed to investigate the effectiveness of computer usage on the achievement of seventh grade students in mathematics, compared to the traditional method, and knowledge of the trends of their teachers towards use it as an educational tool. The sample size was (47) male and female students of the seventh grade. The number of teachers (37) male and female. The students divided into two groups: (24) Experimental, which was studied using the computer, and (23) is a control one who studied in the traditional way. The data was analysed by using SPSS statistical package. The most important results that the researcher reached were the following: There are statistically significant differences on the level of significance $(\alpha=05.0)$ between the averages of students' achievement, in favor of experimental group. There are statistically significant differences due to gender or to the 
interaction between teaching method and gender. There are positive attitudes among the mathematics teachers of the seventh grade towards the use of computer as an educational tool in the teaching of mathematics.

Ogochukwu (2010) study was aimed to verify the preference of high school students for multimedia presentations versus traditional education in mathematics. A questionnaire used for collecting data. The results of the study showed that: multimedia presentations can develop students' preferences, and raise their level of satisfaction with multimedia. The researchers are trying to provide researchers and those interested in the topic of research on the use of multimedia presentations to improve the quality of learning in students' acquisition of skills in the use of computer software and the development of Instant Demo, which is intended for recording events that take place on the lecturer's desktop with image, movement and sound, after which it is stored in flash files image, with the ability for students to access them at any time they need.

Youssef (2009) study was conducted to know the advanced computer design programs, and their relationship with art education programs and their relationship with each other, to develop a curriculum for teaching these programs and to highlight their role in developing students' taste, aesthetic, and technical abilities. The study come out with the following results: there is a relationship between advanced computer design programs, and the Art education curriculum. The computer programs help the artists and facilitate their role to present accurate pictures and drawings saving money and time. Computer programs serve art education students, and help in developing the educational process in general, and art education in particular.

Mohammed (2004) study was aimed to find out the effectiveness of using computer on the academic achievement in physics of the third level student of the Faculty of Education, University of Khartoum. Descriptive analytic approach was used to cover the theoretical aspects along with the experimental approach to cover the applied aspects contained in this research. The sample size was (45) students who divided into two groups: experimental and control groups, the first one used was taught using computer, whereas the second group was taught using the traditional approach in teaching the same subject (heat). The tool used in this research was a pre-test and post-test achievement test for both groups. The researcher used mean values, standard deviations and (T) test to analyses the data. The main findings of the research were: 1. Both groups (experimental and control group) were equal in achievement in the pretest. 2. Using Computer had a positive effect on achievement of the third level students in physics. 3 . There was not statically significant deference due to gender between the two groups. In the light of the above results, the researcher recommends using computer in teaching physics in higher education as well as training teachers on producing computerized tutorial physical program.

Al-Mousa (2002) field study was aimed at diagnosing the reality of computer use in the ministries of education and knowledge in the Arab Gulf states, in terms of planning, the devices they use, the types of programs available to them, and the administrative and educational uses in the basic education stage in order to enhance strengths and address weaknesses in this reality and to form a society. The study is from educational technology officials, and principals of basic education of both sexes in all the countries of the Gulf Cooperation Council. The sample included two main categories: all principals responsible for educational technologies, and principals of primary schools with (40) schools from each country. The researcher used the questionnaire as a main tool for this study. 
Muhammad (2001) study was conducted to find out the impact of Computer use in teaching biology for tenth grade students on students' achievement and attitudes towards computers. The students were divided into control group and experimental group, and to determine the change in the attitudes of the experimental group students towards the use of computers. A questionnaire used to measure students' attitudes towards using computers in teaching. The study come out with the following results: there were statistically significant differences in favor of experimental group, and the necessity of teaching educational materials, including biology, using computers, and conducting more studies on trends in teaching students towards the use of computers, and the need to formulate the school biology subject prescribed for students, so that it is compatible with educational computer programs.

Al-Ajab (2000) study was aimed to reveal the effectiveness of computer and multimedia technology in teaching physics in university colleges, and to identify the impact of this new technology on students' achievement in physics and their attitudes towards learning and studying it. The researcher used the questionnaire as a measurement of trends and the test as a measure of achievement. One of the most important results of the study is that the use of computers and multimedia as a new educational technology has a positive impact on the achievement of university college students in physics, and that the technical treatment proved effective in developing students' trends towards studying and learning physics, and the study also verified the positive attitudes of students towards the subjects taught with computer aid.

\section{Benefit from previous studies}

It is clear from the previous studies, which the researchers see the possibility of benefiting from them in the current research, as all studies aimed at using the computer and its programs and its impact on students, and the development of their skills compared to the traditional methods of teaching, and there are some aspects of agreement and difference between them and this study, which can be summarized in the following points:

1- The current research agrees with some previous studies in the use of computer programs in teaching process, such as Jabr study (2010), Yousef study (2009), Mohammed study (2004), Al-Mousa study (2002), Mohammad study (2001) and Ajab study (2000).

2-Some previous studies agreed with the current research in developing emotional intelligence skills such as Al-Friahat study (2018) and Marzouk study (2013).

3- None of the previous studies uses a computer program (Photoshop) to develop emotional intelligence, but the current study did.

\section{METHODS AND MATERIAL}

\section{Research problem}

The research problem is summarized in the following questions:

1- Are there statistically significant differences between the average performance of the sample members on the emotional intelligence scale in the experimental group before and after the implementation of the training program?

4 Are there statistically significant differences between the average performance of the control group and the experimental group on the emotional intelligence scale.

3- Are there statistically significant differences in the average performance of the experimental group on the emotional intelligence scale due to gender?

4- Are there statistically significant differences in the average performance of the experimental group on the emotional intelligence scale due to age?

\section{Research Goal}

This research aims to know the effectiveness of a computer program based on Photoshop in design and decoration in developing emotional intelligence for children in the age group (11-17 years) in the Jazan 
region, and to identify the differences between the experimental group and the control group on the emotional intelligence scale in addition to the detection of differences between males and females and the differences between the different age groups.

\section{Research Importance}

The importance of the research comes from the importance of the Photoshop program, in that, it is a scientific addition concerned with the technical and technical aspects of computer uses in the arts and its teaching, and in the teaching and learning process and linking artistic material in the field of design and decoration of all kinds, using Photoshop programs in order to develop emotional intelligence for children in the age group (11- 17 years), and the importance of the research is that, it is the first research within the limits of the researchers' knowledge in the use of computerized program (Photoshop) in the development of emotional intelligence, and the study is an extension of study in designing computerized art to develop cognitive skills.

\section{Research Methods}

To achieve the objectives of the study, the researchers chose the quasi-experimental design with equivalent groups, the control group and the experimental group, where all subjects were distributed at all levels of the dependent and independent variable or its treatments into groups related to the dependent variable and then the pre-measurement by applying the IQ scale emotional and then applying the computer program (photoshop) and then applying the post measurement to find out the differences in the pre and post measurements and to know the effect of the program on the emotional intelligence of the sample members.

\section{Research Sample}

The research sample was chosen by stratified random method, which consisted of (44) students (14) males and (30) females from the intermediate and secondary schools in the Jazan region in the age group (11-17 years), who were distributed into two equal groups (22) male and female students for each of the experimental and control groups. Table No. (1) shows the distribution of the research sample.

TABLE I

\section{DESCREPTION OF THE RESEARCH SAMPLE ACCORDING TO THE VARIABLES}

\begin{tabular}{|c|c|c|c|c|c|c|}
\hline \multirow{2}{*}{ Data } & \multicolumn{2}{|c|}{ Gender } & \multicolumn{2}{|c|}{ School } & \multicolumn{2}{|c|}{$\begin{array}{c}\text { Age } \\
\text { Group }\end{array}$} \\
\hline & $\begin{array}{c}\mathrm{Ma} \\
\text { le }\end{array}$ & $\begin{array}{c}\text { Fema } \\
\text { le }\end{array}$ & $\begin{array}{c}\text { Governm } \\
\text { ent }\end{array}$ & $\begin{array}{c}\text { Priva } \\
\text { te }\end{array}$ & $\begin{array}{c}11- \\
13\end{array}$ & $\begin{array}{c}14- \\
17\end{array}$ \\
\hline Number & 14 & 30 & 36 & 8 & 24 & 20 \\
\hline $\begin{array}{c}\text { Percent } \\
\text { age }\end{array}$ & $\begin{array}{l}32 \\
\%\end{array}$ & $68 \%$ & $82 \%$ & $18 \%$ & $\begin{array}{l}55 \\
\%\end{array}$ & $\begin{array}{l}45 \\
\%\end{array}$ \\
\hline Total & & 44 & 44 & & 4 & 4 \\
\hline
\end{tabular}

\section{Research Limits}

The limits of the research are as the following:

1/ Temporal limits: the second semester of the year 1441-1442 AH

2/ Spatial boundaries: Jazan region.

3/Objective limits: the computer program Photoshop in design and decoration and its impact on emotional intelligence.

4/ Human limits: middle and high school students in the age group (11-17 years).

\section{Research Hypotheses}

In light of the previous questions, the study hypotheses can be summarized as follows:

1 - There are statistically significant differences in the average scores of children in the age group (11-17 years) on the emotional intelligence scale pre and post the application of the program in favor of the post application.

2- There are statistically significant differences between the average performance of the control 
group and the experimental group on the emotional intelligence scale in favor of the experimental group.

3- There are statistically significant differences in the average performance of the experimental group on the emotional intelligence scale due to gender

4- There are statistically significant differences in the average performance of the experimental group on the emotional intelligence scale due to age.

\section{Research Tools}

First: The emotional intelligence scale (description of the scale)

The scale was prepared by Bar-On (1999), translated and codified by Safaa Al-Asaar and Alaa El-Din Kafafi. The test consists of (133) items, to be answered by self-report, on a continuum starting from (not fully applicable) to (completely applicable) sub-item, which are as follows:

1- The scale consists of five dimensions:

- the dimension of intelligence within the person, which includes sub-dimensions: emotional selfawareness, assertiveness, self-consideration, selfactualization, independence.

- Interpersonal intelligence includes three subdimensions: empathy, interpersonal relationships, and social responsibility.

2- The ability to adapt, including three subdimensions, namely, problem solving, reality testing, and flexibility.

3- Stress management, which includes two subdimensions: stress tolerance and impulse control.

4- General mood, which includes two subdimensions: happiness and optimism.

The test was re-legalized on the rationing sample, which consisted of (22) male and female students from the intermediate and secondary schools in the Jazan region, and the validity and stability of the scale were calculated, and the following are the coefficients of internal consistency, self-honesty, and the reliability coefficient by retailing the midterms.

\section{Validity and Reliability}

After conducting the arbitration for its standards and the amendment based on the arbitrators' recommendations by deletion and addition, the researchers conducted an exploratory study on it, which included (30) items, in order to ensure the validity and reliability of its tools statistically, and the result of this was:

\section{Validity}

a. Structural validity (internal consistency) of the scale

It means the correlation of each of the items with the total score of the scale. We note that most of the correlations of the scale items are high to an acceptable degree, which prompted the researchers to adopt them, except for items No. $(2,6,9,15)$, where their correlation was weak, which prompted the researchers to delete them. Thus, the number of approved scale items becomes (30) items.

B. The subjective validity of the scale

It means the product of the square root of the Alpha Cronbach stability coefficient, and by looking at the values of the scale stability and by extracting the square root, we find that it is equal to (0.993), which are high values to an acceptable degree, which confirms the validity of the subjective scale and thus its validity for use in the current research.

Scale Stability: Alpha Cronbach Stability

The researchers extracted the final value of Cronbach's alpha stability after deleting the weak items, which amounted to (.987), which is a high value and therefore acceptable, which indicates the stability of the scale and thus its validity for use in the current research.

The stability of the half-segmentation 
The researchers extracted the value of the stability of the scale by the method of split-half in two ways, Spearman-Brown and the Guttman method, which reached, respectively: $(.993, .989)$, which are high values, and therefore acceptable, which indicates that the scale is at a high level of stability.

TABLE 2

THE INTERNAL CONSISTENCY OF THE EMOTIONAL INTELLIGENCE SCALE

\begin{tabular}{|c|c|c|c|c|c|c|c|}
\hline $\begin{array}{l}\mathrm{N} \\
\mathrm{O}\end{array}$ & $\begin{array}{c}\text { Correlati } \\
\text { on }\end{array}$ & $\begin{array}{l}\mathrm{N} \\
\mathrm{O}\end{array}$ & $\begin{array}{c}\text { Correlati } \\
\text { on }\end{array}$ & $\begin{array}{l}\mathrm{N} \\
\mathrm{o}\end{array}$ & $\begin{array}{c}\text { Correlati } \\
\text { on }\end{array}$ & $\begin{array}{l}\mathrm{N} \\
\mathrm{O}\end{array}$ & $\begin{array}{c}\text { Correlati } \\
\text { on }\end{array}$ \\
\hline 1 & .895 & $\begin{array}{l}1 \\
0\end{array}$ & .944 & $\begin{array}{l}1 \\
9\end{array}$ & .973 & $\begin{array}{l}2 \\
8\end{array}$ & .926 \\
\hline 2 & .069- & $\begin{array}{l}1 \\
1\end{array}$ & .931 & $\begin{array}{l}2 \\
0\end{array}$ & .910 & $\begin{array}{l}2 \\
9\end{array}$ & .949 \\
\hline 3 & .943 & $\begin{array}{l}1 \\
2\end{array}$ & .936 & $\begin{array}{l}2 \\
1\end{array}$ & .973 & $\begin{array}{l}3 \\
0\end{array}$ & .933 \\
\hline 4 & .830 & $\begin{array}{l}1 \\
3\end{array}$ & .925 & $\begin{array}{l}2 \\
2\end{array}$ & .346 & $\begin{array}{l}3 \\
1\end{array}$ & .325 \\
\hline 5 & .938 & $\begin{array}{l}1 \\
4\end{array}$ & .880 & $\begin{array}{l}2 \\
3\end{array}$ & .926 & $\begin{array}{l}3 \\
2\end{array}$ & .818 \\
\hline 6 & -.001 & $\begin{array}{l}1 \\
5\end{array}$ & .135 & $\begin{array}{l}2 \\
4\end{array}$ & .292 & $\begin{array}{l}3 \\
3\end{array}$ & .913 \\
\hline 7 & 966 & $\begin{array}{l}1 \\
6\end{array}$ & .773 & $\begin{array}{l}2 \\
5\end{array}$ & .961 & $\begin{array}{l}3 \\
4\end{array}$ & .857 \\
\hline 8 & .799 & $\begin{array}{l}1 \\
7\end{array}$ & .208 & $\begin{array}{l}2 \\
6\end{array}$ & .936 & & \\
\hline 9 & .018 & $\begin{array}{l}1 \\
8\end{array}$ & .982 & $\begin{array}{l}2 \\
7\end{array}$ & .962 & & \\
\hline
\end{tabular}

TABLE 3

VALIDITY AND RELIABILITY OF DIFFERENT TYPES SCALE

\begin{tabular}{|c|c|c|c|c|}
\hline \multirow{2}{*}{ Variable } & Delete & $\begin{array}{l}\text { Alpha } \\
\text { Cronbac }\end{array}$ & $\begin{array}{c}\text { Intern } \\
\text { al }\end{array}$ & $\begin{array}{l}\text { Half Segmentation } \\
\text { Stability }\end{array}$ \\
\hline & Items & $\begin{array}{c}\mathrm{h} \\
\text { Stability }\end{array}$ & $\begin{array}{l}\text { Validit } \\
\text { y }\end{array}$ & $\begin{array}{cc}\text { Spearma } & \text { Guttma } \\
\text { n-Brown } & \mathrm{n}\end{array}$ \\
\hline
\end{tabular}

\begin{tabular}{cccccc}
\hline Emotional & $2,6,9$, & & & & \\
$\begin{array}{c}\text { Intelligen } \\
\text { ce }\end{array}$ & 15 & .987 & .993 & .993 & .989 \\
& & & & &
\end{tabular}

\section{The training program}

The researchers prepared the training program by referring to previous studies and reviewing the theoretical literature on the subject. The program was initially built on the basis of previous literature on the subject. The program was presented to (5) professors of arbitrators from the areas of specialization from the College of Education at Jazan University and Based on the opinions of the arbitrators, some activities and paragraphs of the program have been deleted, added and modified.

\section{Program Duration}

The program consists of (16) training sessions, including the introductory session and the closing session distributed over (8 weeks) at two sessions per week, including the pre- and post-measurement session, and at a rate of two sessions for each skill except for the introductory session and the closing session where the session lasts 45 minutes.

\section{Program procedures and methods used}

\section{Introductory session}

Session's Objectives: Achieving acquaintance between the trainees and researchers, clarifying the objectives of the program and its sessions, and emphasizing the commitment to attendance and participation, as well as the application of tribal measurement.

The researchers presented a list of reinforcers in the session introductory to the trainees to determine through their answers the types of reinforcers desired in general, and placed in the class three boards "the attendance board, the encouragement board, and the homework board" to be used during reinforcement, and the researchers noticed the trainees' admiration for the method of reinforcement. The researchers also provided continuous reinforcement in the first two weeks of implementing the training program, and then began with intermittent reinforcement, whereby researchers explained to the trainees that the conditions for obtaining reinforcements are commitment to homework and attendance. 


\section{Motivation skill sessions}

Session's Objectives: Developing the skill of emotional flexibility and self-control.

Style used: role playing

The researchers used the role-playing method in some of the training program sessions through activities. This appeared through the use of models to represent a role in the integration of shapes and the creation of geometric shapes.

\section{Self-awareness skill Sessions}

Session's objectives: To develop the skill of selfawareness, acceptance and expression.

Style used: story

When using the story method in the training program, the researchers took into account the selection of three purposeful stories through a group of stories from the series of forming the child's personality, by arranging pictures, choosing and comparison between given models. Subtraction, as it is appropriate for the topics of the sessions to the requirements of the situation and personality expressed in the story, and to follow an understandable and easy language and to ensure that all the stories that have been narrated are supported by pictures, by presenting them in the training program.

\section{Comprehension Skill Sessions}

Session's Objectives: Developing the skill of perceiving social relationships

Method used: working in groups

In this method and in many sessions, the researchers used some artistic activities, and through the trainees sitting with each other in a circle to implement some of the activities of the program sessions and practicing free drawing in a competitive atmosphere after distributing them to work groups through realizing social relations in teamwork and cooperation.

\section{Emotional Processing Skill Sessions}

Session's Objectives: Develop the skill of self-reliance Method used: lectures and discussions

The practical side of this method includes providing information to students about emotional intelligence skills and information related to the methods of using Photoshop, explaining the information about the sessions and what is presented in them, paying attention to the technical material and its importance and technical skills, and supporting the creative side through the production of decorative and artistic designs. The researchers used this method in most of the discussion sessions with the trainees on the topics raised in the sessions, and the researchers used training aids such as pictures, films and an information display device when using the technique of lecture and discussion.

\section{The skill of openness and acceptance of others' ideas}

Session's Objectives: To develop the skill of accepting the ideas of others and effective cooperation.

Method used: brainstorming

This method was used by the researchers asking some questions about a specific topic related to the techniques of using Photoshop in the design of advertisements and the formation of decorations with lines and spaces, and asking the trainees to answer them according to what comes to their minds, as well as giving some examples of some of the activities of the sessions.

\section{The skill of good behaviour in different situations}

Session's Objectives: To develop the skill of good behaviour and dealing with feelings

Method used: Problem solving

The researchers used this method, as they explained these steps through the story presented in the session, and a model of incomplete or unorganized artwork was presented in which the trainees were asked to address them, and a set of problems and solutions 
were presented to compare them, and also recall a picture from the computer and make modifications and improvements on it.

\section{Self-motivation skill Sessions}

Session's Objectives: Developing and motivating the skill of self-confidence

Method used: Positive self-talk

The researchers used this method as one of the means to get rid of negative emotions and transform them into positive ones, training in self-control, and providing drawings and designs according to given conditions.

For length, width and height, the researchers used reinforcement and asked the trainees to practice selfreinforcement and self-motivation by placing grades and marks on the required work.

\section{The Closing Session: The Skill of Perceiving Feelings}

Session's Objectives: Developing the skill of perceiving feelings and social empathy and applying telemetry

Method used: Feedback

The researchers used this method with the trainees by reviewing each session from the beginning of the tenth session to the next, and by reviewing the homework at the beginning of each session, and sometimes providing moral and physical reinforcement to the trainees.

\section{Evaluation}

The researchers relied on presenting homework and assignments at the end of each session, where assignments were given to the trainees for training and application of what was done during the session, in addition to asking questions before starting in relation to the previous skill, and during and at the end of the session in relation to the current skill.

\section{Pre and post measurement}

The researchers prepared the study tools, the emotional intelligence scale, the training program, calculating the validity and stability of the scale, presenting the training program to the arbitrators and taking the consent of the parents of the students to participate in the training program and agreeing on dates and place of application, in addition to applying the emotional intelligence scale to a sample exploratory to calculate the validity and reliability of the scale.

The researchers applied the pre-measurement in the introductory session before the actual start of the program, and also applied the scale again in the closing session as a post-measurement.

\section{Analysing of Data}

The researchers used several statistical treatments to process their data, using the Statistical Package for Social Sciences (SPSS) program.

1- Two-tailed T-Test to detect the differences between the two groups

2- Univariate analysis of variance: to reveal differences between interaction groups

3- Post-test (LSD) to determine the direction of differences between groups of interaction variables (group $\mathrm{x}$ application)

\section{III.RESULTS AND DISCUSSION}

\section{A. The first hypothesis}

There are statistically significant differences in the average scores of children in the age group (11-17 years) on the emotional intelligence scale pre and post the application of the program in favor of the post application. 
TABLE 4

TWO-TAILED T-TEST DIFFERENCES IN EMOTIONAL INTELLIGENCE

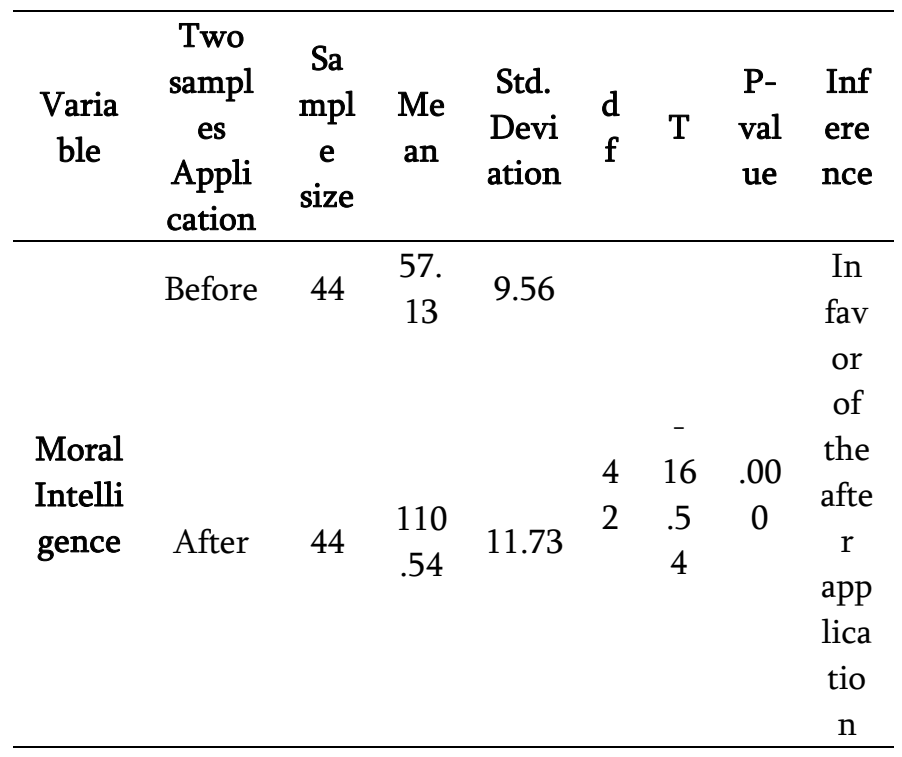

Looking at table 4 , we note that the differences between the sample averages before and after the application of the program are statistically significant, as the calculated $(\mathrm{T})$ value that reached $(-16.54)$, which is a significant value at the level of significance of .01 , where the probabilistic values came (.00). So, the differences are significant, so the result: (There are statistically significant differences in the average scores of children in the age group (11-17 years) on the emotional intelligence scale pre and post the application of the program in favor of the post application).

The result of the first hypothesis agrees with the study (Fraihat, 2018 and Marzouk, 2013 and Youssef, 2009 and Mohammad, 2001), which all indicated the effectiveness of the training program in developing students' skills, as confirmed by Youssef's study, 2009 that the use of computer-based programs plays an important role in developing the educational process and students' basic skills. Al-Ajab, 2000 indicated that training programs develop attitudes and skills for trainees, this is consistent with what was indicated by (El-Sayed, 2004, p. 56) that the educational process began with a transformation in its educational methods from indoctrination to modern methods that keep pace with development using computer programs to help the learner acquire educational competencies that enable him/her to play a positive role, and make him/her able to confront life, to use critical thinking, cognitive and emotional processes, and using advanced information technologies and networks. Education based on indoctrination, and information filling leads to outputs that lack mastery and creative skills, which makes it necessary to provide them with skills through intellectual activities and modern education patterns to build the learner's personality.

\section{B. The second hypothesis}

There are statistically significant differences in the average performance of the experimental group on the emotional intelligence scale due to gender.

\section{TABLE 5}

THE RESUTL OF THE INTERACTION TEST FOR THE DIFFERENCES BETWEEN THE GROUPS OF INTERACTIONOF TWO VARIABLES (GENDER $\times$ APPLICATION)

\begin{tabular}{|c|c|c|c|c|c|c|}
\hline & $\begin{array}{l}\text { Sum of } \\
\text { Squares }\end{array}$ & $\begin{array}{l}\mathrm{d} \\
\mathrm{f}\end{array}$ & $\begin{array}{c}\text { Mean } \\
\text { of } \\
\text { Squares }\end{array}$ & $\mathrm{F}$ & $\begin{array}{c}\text { Sig } \\
\text {. }\end{array}$ & $\begin{array}{c}\text { Infere } \\
\text { nce }\end{array}$ \\
\hline Correcti & 31636.8 & & 10545.6 & 92.56 & .00 & Signifi \\
\hline on form & $20^{\mathrm{a}}$ & 3 & 07 & 5 & 0 & cance \\
\hline Residual & $\begin{array}{c}262717 . \\
732\end{array}$ & 1 & $\begin{array}{c}262717 . \\
732\end{array}$ & $\begin{array}{c}2306 . \\
025\end{array}$ & $\begin{array}{c}.00 \\
0\end{array}$ & $\begin{array}{l}\text { Signifi } \\
\text { cance }\end{array}$ \\
\hline Gender & & & & & & \\
\hline$x$ & 31636.8 & 3 & 10545.6 & 92.56 & .00 & Signifi \\
\hline $\begin{array}{l}\text { Applicat } \\
\text { ion }\end{array}$ & 20 & & 07 & 5 & 0 & cance \\
\hline Error & $\begin{array}{c}4557.06 \\
7\end{array}$ & $\begin{array}{l}4 \\
0\end{array}$ & 113.927 & & & \\
\hline Total & $\begin{array}{c}345483 . \\
000\end{array}$ & $\begin{array}{l}4 \\
4\end{array}$ & & & & \\
\hline $\begin{array}{c}\text { Total } \\
\text { Correcti } \\
\text { on }\end{array}$ & $\begin{array}{c}36193.8 \\
86\end{array}$ & $\begin{array}{l}4 \\
3\end{array}$ & & & & \\
\hline
\end{tabular}

In table 5, we note that there are statistically significant differences between the groups of 
coefficients of the two variables (gender $x$ application), where the calculated (F) value reached (92.56) the value of the value of the value at the level of significance of .01, where the probabilistic value is $(.00)$, and to know the direction of the differences, the researchers used the post-test (LSD) where the results were as follows:

TABLE 6

POST-TEST (LCD) TO DETERMINE THE

DIRECTION OF DIFFERENCES BETWEEN THE GROUPS OF INTERACTION OF TWO VARIABLES (GENDER $\times$ APPLICATION)

\begin{tabular}{|c|c|c|c|c|c|c|c|}
\hline \multirow[b]{2}{*}{ Data } & \multicolumn{3}{|c|}{ descriptive } & \multirow[b]{2}{*}{$\begin{array}{c}\text { Comparison } \\
\text { Groups }\end{array}$} & \multirow{2}{*}{$\begin{array}{c}\text { Mean } \\
\text { Differe } \\
\text { nce }\end{array}$} & \multirow[b]{2}{*}{$\begin{array}{l}\mathrm{Si} \\
\text { g. }\end{array}$} & \multirow[b]{2}{*}{ Inference } \\
\hline & $\mathrm{N}$ & $\begin{array}{c}\text { Mea } \\
\mathrm{n}\end{array}$ & $\begin{array}{c}\text { Std. } \\
\text { Deviat } \\
\text { ion }\end{array}$ & & & & \\
\hline
\end{tabular}

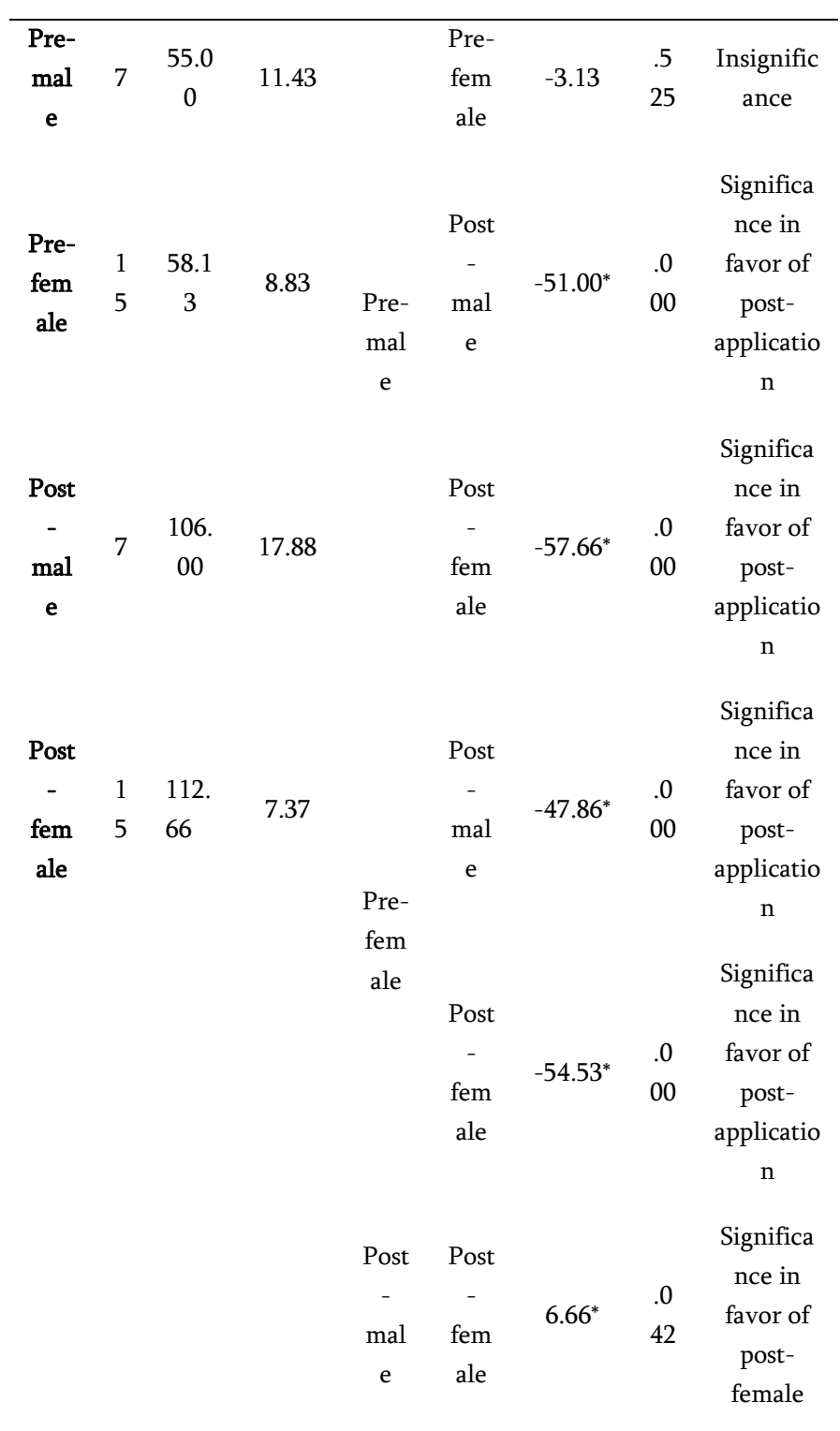

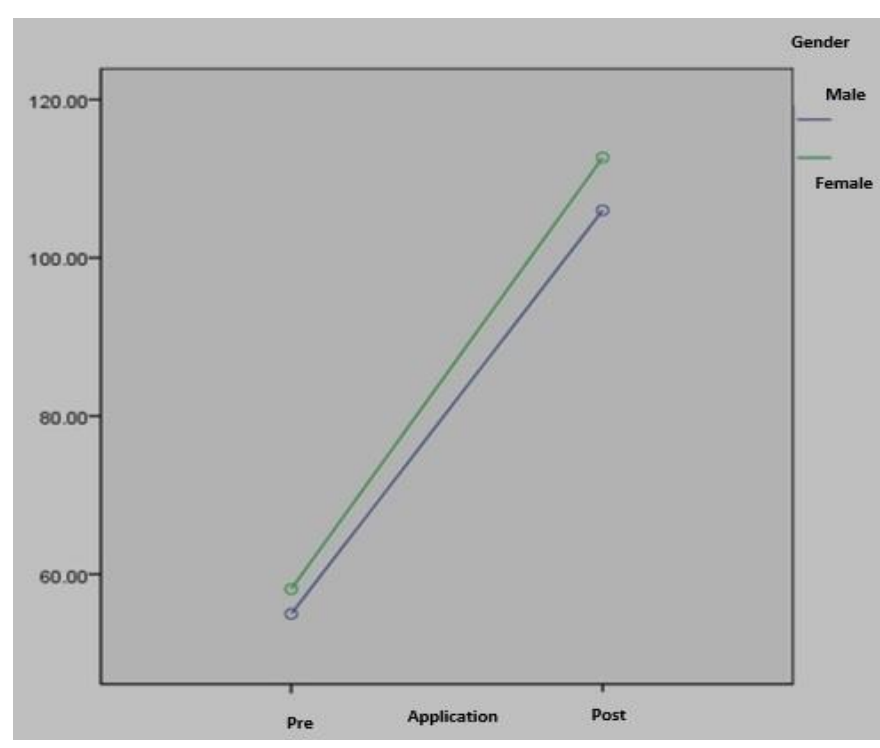

FIGURE 1: THE DIFFERENCES BETWEEN THE INTERACTION GROUPS OF THE VARIABLES OF $($ GENDER $\times$ APPLICATION)

We note from the table 6 , and figure 1 , that the highest degree of achievement was achieved for females with average reached (112.66) degrees, with a difference of $\left(-6.66^{*}\right)$ from the males group average, in the post application, which is a statistically significant difference at the lowest level of significance .05. So, the result: (There is Statistically significant differences in the average scores of (11-17) year old children on the emotional intelligence scale between groups of interaction variables (application $\times$ gender) in favor of females in the post application.

This means that females benefit more from the program than males. The current research differs from (Al-Fraihat, 2018 study and Marzouk, 2013 study), which concluded that there are no significance differences between males and females in the post application, in contrast to what the current research has found, that, there are differences between males and females in favor of females. The axes of emotional intelligence are the ability to be aware of the individual's feelings and emotions. The individual's awareness of his/her feelings and the feelings of others, their understanding and awareness of them, and his ability to control his/her feelings, enable him/her to extrapolate the feelings of others 
and control his/her emotions. The use of emotions and feelings, controlling, and directing them in the individual and others helps in social interaction with others and empathy with their feelings (Abu Al-Nasr, 2008, p. 332).

\section{The Third Hypothesis}

There are statistically significant differences in the performance averages of the experimental group on the emotional intelligence scale due to age.

TABLE 7

THE RESULT OF INTERACTION TEST FOR THE

DIFFERENCES BETWEEN THE GROUPS OF

INTERACTION OF TWO VARIABLES (AGE $\times$ APPLICATION)

\begin{tabular}{ccccccc}
\hline & $\begin{array}{c}\text { Sum of } \\
\text { Square } \\
\mathbf{s}\end{array}$ & df & $\begin{array}{c}\text { Mean } \\
\text { of } \\
\text { Squares }\end{array}$ & F & $\begin{array}{c}\text { Sig } \\
\cdot\end{array}$ & $\begin{array}{c}\text { Infere } \\
\text { nce }\end{array}$ \\
\hline $\begin{array}{c}\text { Correc } \\
\text { tion }\end{array}$ & $\begin{array}{c}31935 . \\
153^{\mathrm{a}}\end{array}$ & 3 & $\begin{array}{c}10645.0 \\
\text { form }\end{array}$ & 99.98 & .00 & Signifi \\
Residu & 304365 & 1 & 304365. & 2858. & .00 & Signifi \\
al & .103 & 1 & 103 & 738 & 0 & cance \\
Age $\times$ & 31935. & 3 & 10645.0 & 99.98 & .00 & Signifi \\
Applic & 153 & 3 & 51 & 3 & 0 & cance \\
ation & 153 & & & & & \\
Error & 4258.7 & 40 & 106.468 & & & \\
& 33 & & & & & \\
Total & 345483 & 44 & & & & \\
Total & .000 & & & & & \\
Correc & 316193 & 43 & & & & \\
tion & .886 & & & & & \\
\hline
\end{tabular}

*Significant differences at the level of significance (0.05)

From table 7, we note that there are statistically significant differences between the two variables interaction groups (age $\mathrm{x}$ application), where the calculated (F) value reached (99.98), which is a function value at the level of significance of .01, where the probabilistic value is (.00), and to know the direction of differences, the researchers used the posttest (LSD) where the results are as follows:

TABLE 8

POST-TEST (LCD) TO DETERMINE THE

DIRECTIOB OF DIFFERENCES BETWEEN THE GROUPS OF INTERACTION OF TWO VARIABLES $($ AGE $\times$ APPLICATION)

\begin{tabular}{cccccccc}
\hline & \multicolumn{4}{c}{ descriptive } & & Mea & \\
\cline { 2 - 3 } Data & & & Std. & Compariso & $\mathbf{n}$ & Si & Infere \\
& $N$ & $\begin{array}{c}\text { Me } \\
\text { an }\end{array}$ & $\begin{array}{c}\text { Devi } \\
\text { ation }\end{array}$ & n Groups & $\begin{array}{c}\text { Diffe } \\
\text { rence }\end{array}$ & g. & nce \\
& & & & & &
\end{tabular}

\begin{tabular}{cccccccc}
\hline Pre- & & & & Pre- & & \\
Cate & 1 & 60. & & cate & & \\
gory & 2 & 58 & 8.36 & gor & 7.58 & 9 & Insigni \\
1 & & & & y 2 & & 4 & \\
& & & & & &
\end{tabular}

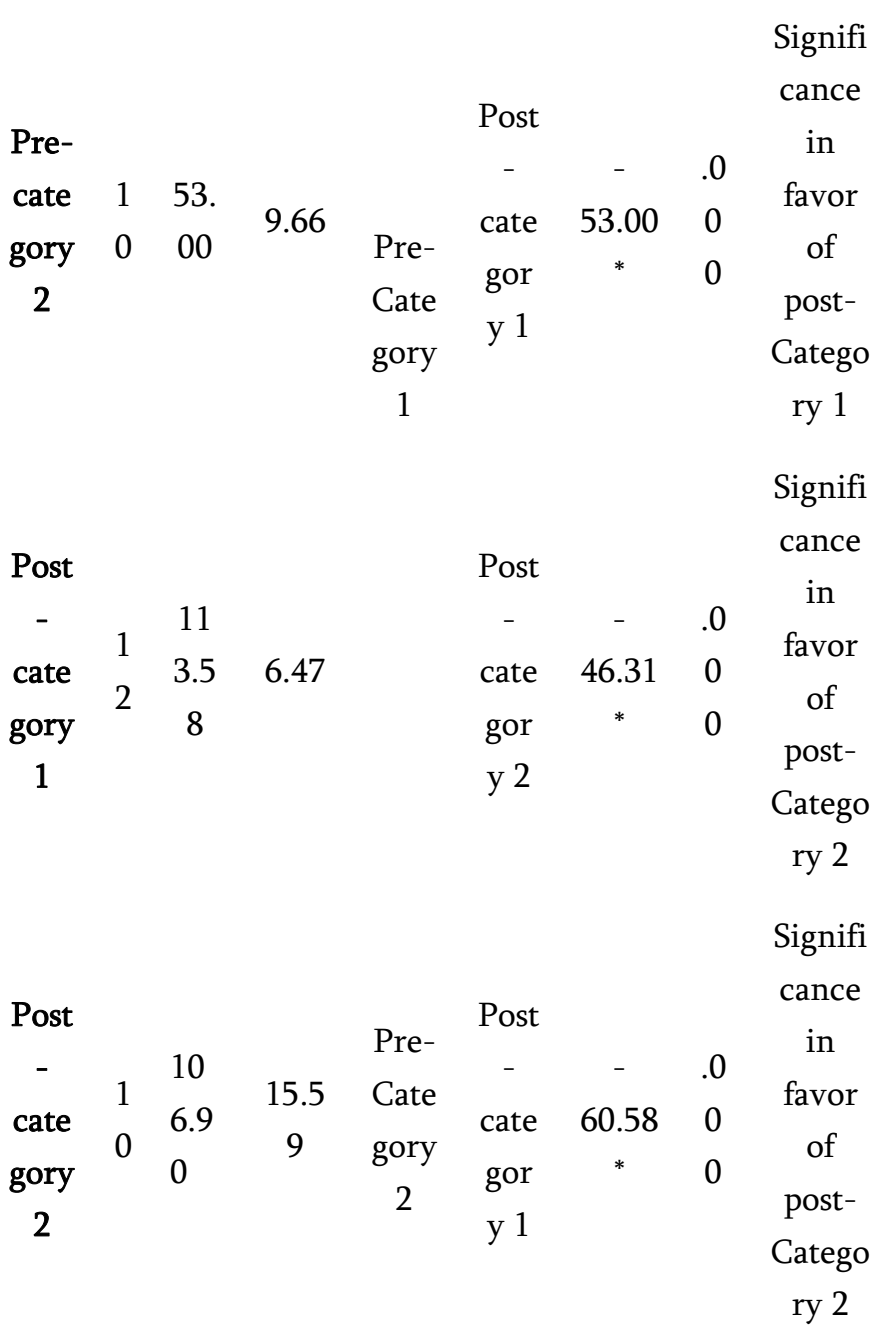

Signifi avor postCatego Signifi ance postCatego Signifi ance favor of Catego ry 2 


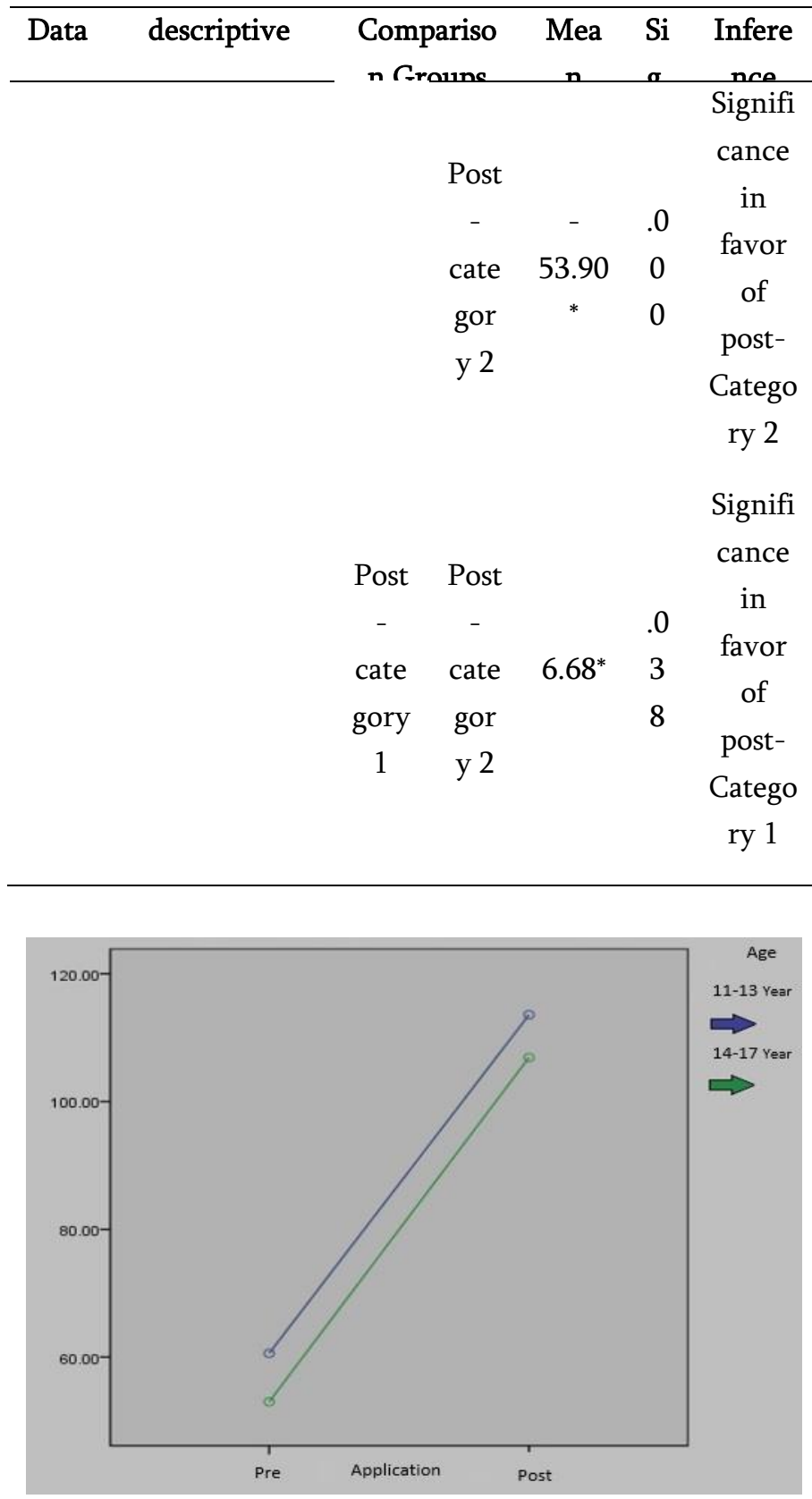

FIGURE 2: THE DIFFERENCES BETWEEN THE INTERACTION GROUPS OF THE VARIABLE OF

\section{$($ AGE $\times$ APPLICATION)}

We note from table 8 and figure 2 that, the highest degree of achievement was achieved in the age group (11-13) years old, with the average reached (113.58) degrees, with a difference of $\left(-6.68^{*}\right)$ from the age group (14-17) years old, in the post application, which is Statistically significant difference at the lowest significance level .05. So, the result: (There are statistically significant differences in the average scores of (11-17) year old children on the emotional intelligence scale between groups of variable interaction (application $\mathrm{x}$ age) in favor of the age group (11-13) years old, in the post application. None of the previous studies mentioned a reference to the age variable, while the hypothesis result agrees with what was mentioned in the research literature in reference (Cheng and Lynn: 2017, p.112), which mentioned that the most important component of emotional intelligence is self-awareness, which means awareness of the individual's feelings, personal emotions and mood. Self-awareness is the basis of self-confidence and efficiency in managing it, and it is the basis on which the individual relies in making his various life decisions, as awareness of age is linked in a direct relationship (Mustafa, 2005 AD, p. 19).

\section{The Fourth Hypothesis}

There are statistically significant differences in the average scores of children (11-17) years on the emotional intelligence scale between the groups of variables of program application and School type.

\section{TABLE 9}

THE RESULT OF THE INTERACTION TEST FOR THE DIFFERENCES BETWEEN THE GROUPS OF INTERACTION OF TWO VARIABLE (SCHOOL $\times$ APPLICATION)

\begin{tabular}{|c|c|c|c|c|c|c|}
\hline & $\begin{array}{l}\text { Sum of } \\
\text { Squares }\end{array}$ & $\begin{array}{l}d \\
f\end{array}$ & $\begin{array}{c}\text { Mean } \\
\text { of } \\
\text { Squares }\end{array}$ & F & $\begin{array}{c}\text { Sig } \\
.\end{array}$ & $\begin{array}{c}\text { Inferenc } \\
\text { e }\end{array}$ \\
\hline $\begin{array}{l}\text { Correcti } \\
\text { on form }\end{array}$ & $\begin{array}{c}31813.4 \\
42^{\mathrm{a}}\end{array}$ & 3 & $\begin{array}{c}10604.4 \\
81\end{array}$ & $\begin{array}{c}96.83 \\
5\end{array}$ & $\begin{array}{l}.0 \\
00\end{array}$ & $\begin{array}{c}\text { Significa } \\
\text { nce }\end{array}$ \\
\hline $\begin{array}{c}\text { Residua } \\
1\end{array}$ & $\begin{array}{c}195584 . \\
490\end{array}$ & 1 & $\begin{array}{c}195584 . \\
490\end{array}$ & $\begin{array}{c}1785 . \\
978\end{array}$ & $\begin{array}{l}.0 \\
00\end{array}$ & $\begin{array}{c}\text { Significa } \\
\text { nce }\end{array}$ \\
\hline $\begin{array}{l}\text { Age } \times \\
\text { Applica } \\
\text { tion }\end{array}$ & $\begin{array}{c}31813.4 \\
42\end{array}$ & 3 & $\begin{array}{c}10604.4 \\
81\end{array}$ & $\begin{array}{c}96.83 \\
5\end{array}$ & $\begin{array}{l}.0 \\
00\end{array}$ & $\begin{array}{c}\text { Significa } \\
\text { nce }\end{array}$ \\
\hline Error & $\begin{array}{c}4380.44 \\
4\end{array}$ & $\begin{array}{l}4 \\
0\end{array}$ & 109.511 & & & \\
\hline Total & $\begin{array}{c}345483 . \\
000\end{array}$ & $\begin{array}{l}4 \\
4\end{array}$ & & & & \\
\hline $\begin{array}{l}\text { Total } \\
\text { Correcti } \\
\text { on }\end{array}$ & $\begin{array}{c}36193.8 \\
86\end{array}$ & $\begin{array}{l}4 \\
3\end{array}$ & & & & \\
\hline
\end{tabular}


From table 9, we note that there are statistically significant differences between the interaction groups of the two variables (school $\times$ application), where the calculated (F) value reached (96.83), which is a function value at the level of significance of .01 , where the probabilistic value reached (.00), and to know the direction of the differences, the researchers used the post-test (LSD) where the results are as follows:

TABLE 10

POST-TEST (LCD) TO DETERMINE THE

DIRECTION OF DIFFERENCES BETWEEN THE GROUPS OF INTERACTION OF TWO VARIABLE $(\mathrm{SCHOOL} \times$ APPLICATION)

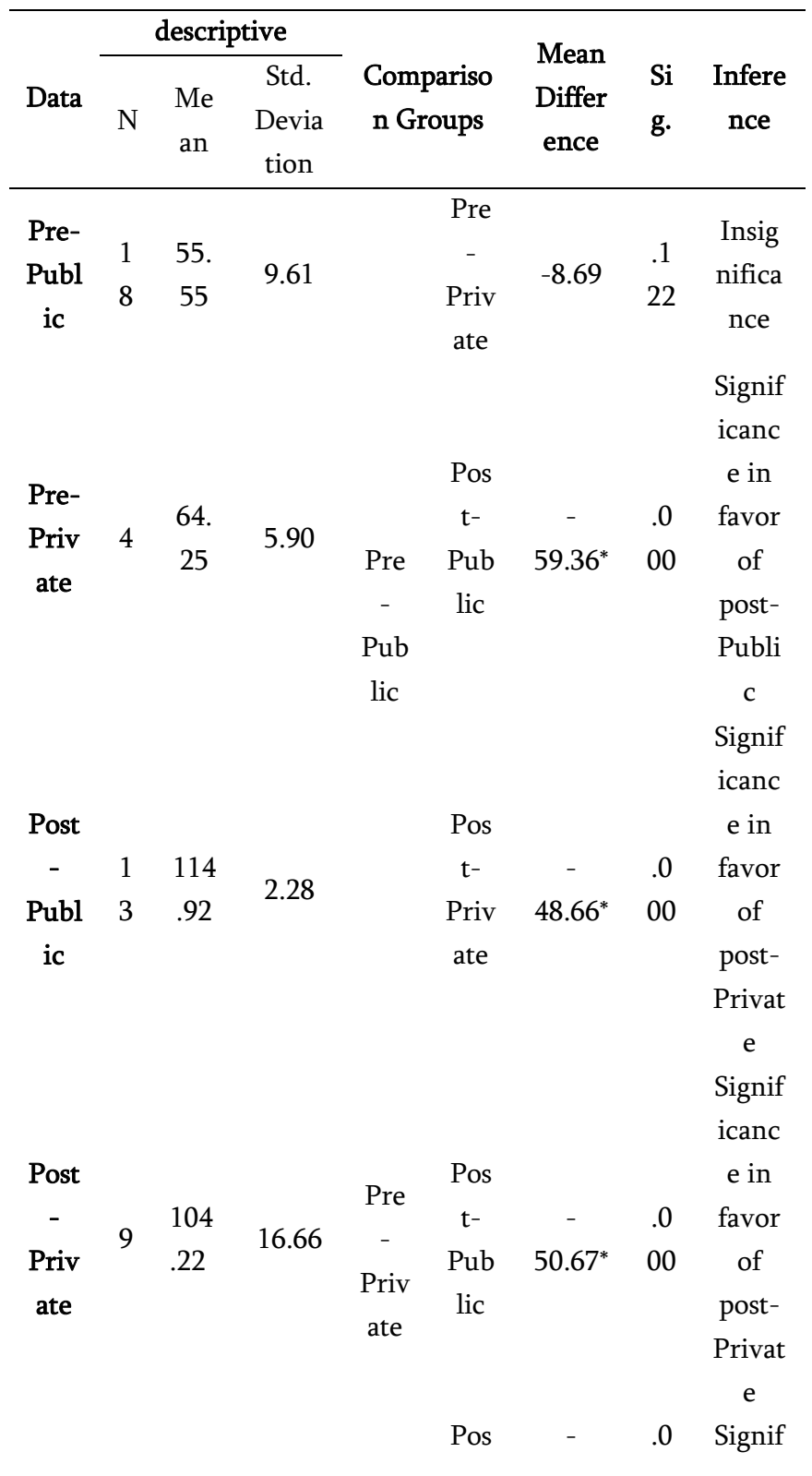

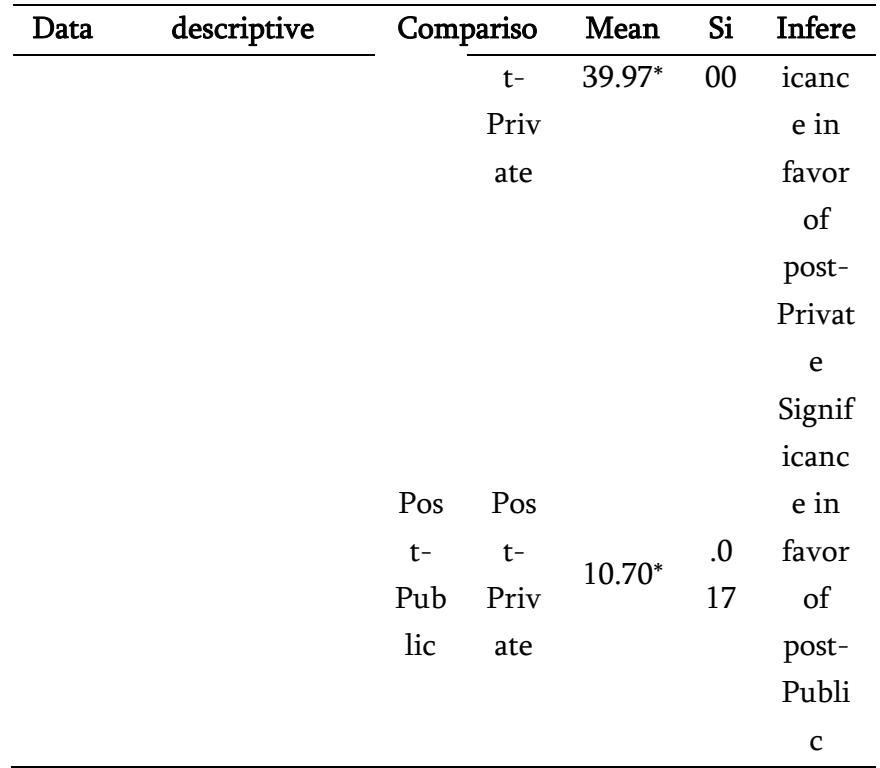

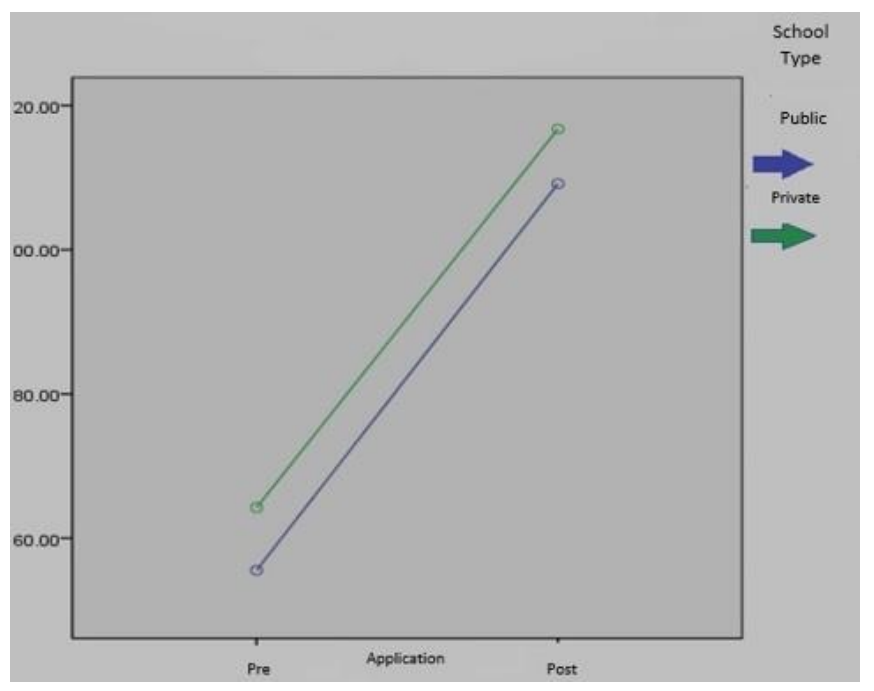

FIGURE 3: THE DIFFERENCES BETWEEN THE INTERACTION GROUPS OF THE VARIABLE OF (SCHOOL TYPE $\times$ APPLICATION)

We note from table10 and figure 3 that, the highest degree of achievement was achieved for the average category of public-school students which reached (114.92) degrees, with a difference of $\left(10.70^{*}\right)$ from the average of private school students in the post application, which is a statistically significant difference at the lowest level of significance .05. So, the result: (There are statistically significant differences in the average scores of children (11-17) years on the emotional intelligence scale between groups of interaction variables (application $\times$ school 
type) in favor of the public-school pupils' category in the post application.

There was no reference in previous studies to the effect of the school type and the research was unique. The current research interest in this aspect, and the results confirmed the existence of differences between private education and government education in favor of public education, and it was mentioned (Hassan Al-Basha, 1994, p. 88) that the use of computers in the educational process and in technical programs provides learners with new horizons and many possibilities for art and creativity when designing decorative painting, which is to produce complex designs accurately and easily, saves time, effort, suffering, retaining and storing items and art forms, and quickly recovering some stored items. It also increases designer's' mental capacity, which help him/her in making infinite formulations in building a single work. Governmental schools are interested in preparing computer labs as basic learning resources as well as digital libraries, in their curriculum.

\section{CONCLUSION}

The research concluded that:

1- There are statistically significant differences in the average scores of children in the age group (11-17 years) on the emotional intelligence scale pre and post the application of the program in favor of the post application.

2- There are statistically significant differences in the average scores of (11-17) year old children on the emotional intelligence scale between groups of interaction variables (gender $\times$ application) in favor of female gender.

3- There are statistically significant differences in the average scores of (11-17) year old children on the emotional intelligence scale between groups of variable interaction (age $\mathrm{x}$ application) in favor of the age group (11-13) years old.
4- There are statistically significant differences in the average scores of children (11-17) years on the emotional intelligence scale between groups of interaction variables (school type $\times$ application) in favor of the public-school.

\section{REFERENCES}

[1]. Abdel-Baqi, Sami Hussein (1989). Using the computer to programming the structural and aesthetic capabilities of the textile design process, unpublished (Ph.D. Thesis), Faculty of Applied Arts, Helwan University.

[2]. Abu Al-Nasr, Medhat Muhammad (2008). Education and Psychology (Developing Emotional and Emotional Intelligence), first edition, Dar Al-Fajr for Publishing and Distribution, Cairo.

[3]. Abu Hatab, Fouad; Sadiq, Amal (2000): Educational Psychology - Sixth Edition - AngloEgyptian Library - Cairo.

[4]. Al- fraihat, Muhammad (2018). The effectiveness of a training program to develop emotional intelligence skills for students of King Abdullah II School for Excellence in Ajloun Governorate. Journal of Psychological and Educational Sciences, 6, (2), pp. 448-467. Available at: https://scholar.google.com/citations

[5]. Al- Mousa, Abdullah Bin Abdelaziz (2002). The use of information and computer technology in basic education in the Gulf countries. AlRiyadh, Arab Bureau of Education for the Gulf States.

[6]. Alajab, Alajab Mohamed (2000). Using Computer and Multimedia Technology in Teaching Specific Topics of Physics in University Colleges. Unpublished (Ph.D. Thesis), College of Education, University of Khartoum. 
[7]. Al-Basha, Hassan (1994). Encyclopedia of Islamic Architecture and Arts, Egyptian Lebanese House, Cairo

[8]. Al-Hariri, Awatef Ismail Adam (2004). Using the Computer in Teaching Art Education to First Level Students of the College of Education, an unpublished (Master Thesis), College of Education, University of Khartoum.

[9]. Cheng \& Lynn. R., (2017). Between Intelligence, Head circumference and Height correlation: Evidence from two samples in Saudi Arabia, Journal of Biosocial Science, pp. 276280,

[10]. El-Sayed, Atif (2004). Information technology, computer educators and interactive video, Taiba House for Printing, first edition, Cairo.

[11]. Fikri, Ahmed (2000). Architecture and Artifacts, UNESCO Publications Center, Cairo.

[12]. Hamid, Abdul Aziz (1982). Decorative Arts, Baghdad, Educational Al Ratib House.

[13]. Jabr, Waheeb Wajeh (2010). The effectiveness of computer usage on the achievement of seventh grade students in mathematics and their teachers' attitudes towards using it as an educational tool. (Master thesis) in Mathematics Teaching Methods at the Faculty of Graduate Studies at An-Najah National University in Nablus, Palestine. Available at: https://scholar.najah.edu/sites/default/files/allthesis/effect_using_computer_graders.pdf

[14]. Khallad, Saad El-Din (2002). Professional Photo Shop in Seven Days, Arab House of Science, Lebanon.

[15]. Marzouk, Essam Ali; Al-shrbeni, Atif Mosad (2013). The effectiveness of a training program in developing emotional intelligence and its impact on developing social skills for children with attention deficit hyperactivity disorder in the primary school. Journal of Educational and Human Studies, College of Education, Damanhour University, Volume 5, (4), Part Two.
[16]. Marzouk, Mohamed Abdel Aziz (1988). Ottoman Arts, the Egyptian General Book Organization.

[17]. Mayer, J. D., \& Salovey. P., \& Caruso. D., (2000). Emotional Intelligence meets Traditional Standards for intelligence. Journal of Intelligence, pp. 267-298.

[18]. Mohammad, Salah Lutfi Ahmed (2001). The Impact of Computer Use in Teaching Biology for Tenth Grade Students on Students' Achievement and Attitudes towards Computers, an unpublished (Master Thesis), College of Education, University of Jordan.

[19]. Mohammed, Yasir Mohamed (2004). The use of computers in teaching physics to students, the third level in the Faculty of Education at the University of Khartoum. (Master Thesis) in education, Presented to the University of Khartoum, College of Graduate Studies, College of Education, Department of Curriculum and Instruction.

[20]. Mustafa, Muhammad Muhammad Yahya (2005). Computer design and technical direction, Al-Khabti Library, Kingdom of Saudi Arabia.

[21]. Ogochukwu, Nwaocha Vivian. (2010). Enhancing students' interest in mathematics via multimedia presentation. Journal of Mathematics and Computer Science Research, 3(7), 107-113,

[22]. Rashwan, Hussein (2005): Teaching innovative thinking skills - The Arab Journal for Special Education - (15) - issued by the Arab Academy for Special Education - Riyadh - Saudi Arabia.

[23]. Samadouni, Ibrahim, (2007). Emotional Intelligence, its Applications and Development, first edition, Dar Al-Fikr for Publishing and Distribution, Amman - Jordan

[24]. Smith, Jennifer (2021). What is photoshop? American Graphic Institute, published on April 6, 2021. Available at: https://www.agitraining.com/design- 
news/photoshop-training-news/what-

photoshop

[25]. Yousef, Khalid Abdeazeem (2009). The Importance of Using Advanced Design Computer Programs in Developing the Skills of Art Education Students, (Master Thesis) submitted to Sudan University of Science and Technology. Available at: http://repository.sustech.edu/handle/123456789 $/ 2827$ ?show=full

[26]. Zaki, Mohamed Abdel Moneim (1996). Art and Design, Deposit No. 10490

[27]. Zee, K., \& Wabeke, R. (2004). Is TraitEmotional Intelligence Simply or More Than Just a Trait? European Journal of Personality, 18, pp. 243-263.

\section{Cite this article as :}

Mahasin Gad Alla Mohamed, Khalida Mohammed Mahmoud, Abeer Amir Bashir, "The Effectiveness of a Computer Program Based on Photoshop in Design and Decoration and Its Impact on Emotional Intelligence Among Children Aged (11-17 Years) At Jazan Region, Kingdom Saudi Arabia ", International Journal of Scientific Research in Science and Technology (IJSRST), Online ISSN : 2395-602X, Print ISSN : 2395-6011, Volume 8 Issue 3, pp. 670-690, May-June 2021. Available at doi : https://doi.org/10.32628/IJSRST2183144

Journal URL : https://ijsrst.com/IJSRST2183144 